\title{
Mongol Familiarisation with European Medical Practices in the Nineteenth-Twentieth Centuries
}

\author{
Batsaikhan Norov \\ Independent researcher, Oxford, United Kingdom \\ bsaikhan4@gmail.com \\ Binderiya Batsaikhan \\ Independent researcher, Oxford, UK \\ binderiya.batsaikhann@gmail.com \\ Batchimeg Usukhbayar \\ Researcher, Weatherall Institute of Molecular Medicine, University of Oxford, \\ Oxford, UK \\ batchimeg.usukhbayar@imm.ox.ac.uk
}

\begin{abstract}
It was primarily Russian activities in Mongolia between 1860 and 1921, reflecting its geopolitical interests, that introduced European medical practices to the Mongols. Competing alongside other European powers, the Russian Government capitalised on conditions within Mongolia to increase Mongolia's dependency on Russia. Thus, the Russian government's motives for medical intervention, like that of other European groups, were mainly political, economic and cultural. In the context of Buddhist dogmatism and the expansive territorial distances between the Mongols (a term this paper uses to encompass all people of Mongol ethnicity in northern and central Asia), the reluctance of Russian doctors to disseminate European medical knowledge prevented its spread into Mongolia. Medical intervention was primarily a method of colonisation justified through healthcare support. Ultimately the familiarisation of European medicine in Mongolia was the first crucial step towards the amalgamation of traditional Mongolian and European medical practices after the Mongolian People's Revolution.
\end{abstract}




\section{Keywords}

European medicine in Mongolia - Russians in Mongolia - missionaries in Mongolia Mongolian traditional medicine - medical colonialism

\section{Introduction}

The Russian government's attempts to increase influence in Inner Asia between 1860 and 1921 were the most successful, in comparison with other European groups, in familiarising Mongols with European medicine. Primarily a result of the Russians' opportunism, which both helped and exploited the inadequate aspects of Mongolian healthcare, European medical knowledge was utilised to promote colonial interests in Mongolia. Typically, due to Mongolian indifference to European regional distinctions in medicine particularly before the early twentieth century, 'European medicine' was ultimately viewed as any evidence-based medicine imported from Europe. It is this view of European medicine that this paper will assume. The scientific methodological basis of European medicine made it more efficient in situations of urgent care, surgical practices and infectious diseases, and thus more attractive over time, in comparison to the more holistic traditional Mongolian medicine. Due to their geographical proximity to Mongolia as well as their political interests in Inner Asia, Russian authorities used medical support as a tool in increasing rapport between the two nations and extending their political influence. Their reach was most significantly limited by the dominance of the Qing authorities in Mongolia, a power derived from the proximity of Mongolia to China. Ironically, though Mongolia's connections to Russia in the north facilitated the use of European medicine in those regions, the greater dominance of the Qing inhibited its dissemination as an indirect consequence of their endeavour to undermine Russian imperial efforts. It is also important to recognise the indirect role of the Qing in increasing medical support from some European missionaries, who had to pass through Mongolia to reach the Qing capital-though this was not that frequent, since Western Europeans mainly travelled by sea to China. Their work therefore was minimal compared to the systematic deployment of doctors by the Russian government. Especially after the Treaty of Peking gave new rights to Russia in 186o, until the declaration of Mongolian independence from Qing powers in 1911, and subsequently the Mongolian People's Revolution in 1921 when Mongolians began to increasingly depend on Russia for political support, the influence of Russia became ever more apparent. Thus, though the reports by Russians that emphasise their significance in the introduction of European medicine into Mongolia are somewhat pompous, we argue that 
this is for the most part true, as their relations with Mongolia made the most prominent and long-lasting impact in Mongolian healthcare.

However, the introduction of European medicine into Mongolia was not smooth. Both the political role of the Qing and later the Russian hegemony were significant in limiting the Mongols' European knowledge. This was combined with other factors such as Mongolia's ethnic and political divisions, as well as the vastness of the Mongol territories both within and beyond Mongolia, which ultimately prevented the efficient dissemination of European medical knowledge. The northern (otherwise known as Outer) region of Mongolia, southern (or Inner) Mongolia, as well as Xinjiang (formerly known as Dzungaria), along with some western Mongol ethnic groups in Qinghai, were all administered by the Qing government. Inhabitants of these regions were for the most part much less familiar with European medicine than the Mongolic Kalmyks, Buryats, and some other western Mongol ethnic groups in the northern Altai region, that were governed by the Russian Empire. Earlier, both great powers, seeing the value of expanding their territory and forces, had held a series of negotiations that created the Treaty of Kyakhta in 1727. For the Russians, this secured their hold on the newly occupied areas of Buryatia and Siberia. The Qing, in turn, attained greater control over the rest of the Mongolian lands, allowing them to restrict all Russian activity, including medical activity, in the majority of Mongolia. Those Mongols with more contact with Russia not only had access to Russian doctors sooner, but also received some medical support from Russian traders, who viewed providing Mongolian healthcare as a way of bettering their relations and stimulating trade. The experiences of Russian missionaries, traders and travellers who found Mongolian medicine to be inadequate galvanised Russian support of Mongolian healthcare, and ultimately overpowered the prevalent traditional Buddhist treatments provided by monastic institutions. Another major divisive force resulted from the tensions between open-minded monastic physicians and the suspicious monks, typically of the older generation, whose conservatism, paired with the lack of trained Mongolian practitioners in European medicine, had significantly inhibited the spread of European medical knowledge and practices.

Janes and Hiliard's (2008) assertion that 'the development of traditional medicine [from the 199os] is entangled with several national and transnational social, cultural, and economic processes' refers to the significant period before the Mongolian People's Revolution that will be discussed in this paper. Through Russian-European interests in Mongolia (and Mongolian interests in Europe) at this time, the foundations for the transformation of Mongolian medical care were created. European identification of the gaps in Mongolian medical knowledge drove efforts to provide services to improve it, both for their own benefit and that of the Mongols. The identification of these gaps 
had both created the opportunity for foreign powers to gain Mongolian trust and also inspired Mongolians to seek out knowledge to better their own medical understanding. Thus, for both foreign powers and Mongolians, familiarisation with European medicine was driven by the desire to increase medical intervention, especially regarding surgical procedures that were banned under Tibetan Buddhism, and the prevention of infectious diseases. It was fortunate for the European powers that this support also extended their influence into Inner Asia.

The Russian ethnographer Ivan Maiskii ([1921] 2005: 115) emphasised the effects of Russian activity among European influences in Mongolia. This was especially evident after the Russian government's realisation of the political and economic benefits of supporting Mongolian healthcare. Growing colonial interests in Mongolia and Inner Asia were justified by both sympathetic and opportunistic Russian officials by the provision of medical support. Through the negotiation of serial treaties, including the Treaty of Aigun in 1858, the Treaty of Beijing in 186o and the Treaty of St Petersburg in 1881, Russia increased its intervention in Mongolia; significantly, this was done by establishing several consulates that provided the main European medical intervention in the country. Russian-European medical units and staff were dispatched throughout the late nineteenth and early twentieth centuries. In this way, the Russian government successfully capitalised on the shifting political situation of the late nineteenth century. The Mongolians' desire for independence from Qing rule encouraged their dependence on Russia and undermined Qing hegemony. This, along with the weakening of Qing authority, allowed the Russians secretly to support Mongolian autonomy from the Qing in 1911.

The lack of training in European medicine amongst the Mongols suggests a level of manipulation, also enabled by the vulnerable political state of the country at the time. As the availability of European medicine was provided almost exclusively by Europeans, especially the Russians, the Russian government was able to encourage political reliance on them indirectly while discouraging Mongolian self-sufficiency. Thus, despite the evident desire of the Mongolians to learn, the Russian government in the late nineteenth century never supported the Mongolians in integrating European medicine into their own medical practices. Some Mongolian aristocrats actively sent requests to the Russian consulate to initiate training on European medicine for their relatives and lamas (Filin 2017:53), but for unknown reasons, there is no evidence 
of this training or anything similar ever taking place, indicating the lack of effort made by the Russians to provide this. In some ways, complying with the requests would have threatened the power balance in Mongolia. Despite having earlier supported the Mongolian attainment of autonomy from China, General Consul V.F. Lyuba (who had been general consul twice in Urga from 1904-06 and 1911-13) threatened Bogd Gegen, the Mongolian leader, with the possibility of withdrawing Russian support to Mongols in an attempt to deter the independence movement against the Qing at this time. Though this was to benefit Chinese authority in Mongolia, it particularly highlights the fact that support provided by Russia to Mongolia was contingent on their submission to Russian commands. This is why we can argue that from the mid nineteenth century, in the context of poor healthcare in Mongolia, European medical support was used by the Russians as a tool to ensure Mongolian compliance in order to increasing their influence over Mongolia during this time.

Though rarely, Russia did make efforts before the mid nineteenth century, for example by administering the smallpox vaccination among the Buryat Mongols. German physician Joseph Rehmann's (1779-1831) efforts in vaccinating the Buryat in 1806 were the most notable (Bawden 1973). According to Bawden, he had been influenced by a staff-surgeon named Petroff (a man whose first name was never specified) who performed 700 vaccinations in Troitskosavsk. ${ }^{1}$ Rehmann's contact with the Buryat had occurred during his work as a doctor for a Russian diplomatic mission attempting to increase Russian trade in China during 1805-06 (Loewenthal 1970-71). The Buryats' proximity and political subservience to the Russians under the Treaty of Kyakhta in 1727 was significant in their being the first Mongol ethnic group to have experienced the smallpox vaccination, ahead of other Mongols under the control of the Qing: the Buryat, being Russian subjects, had more contact with organisations such as Rehmann's mission. This was also a reason for this practice not being passed on immediately to other Mongols as they were more detached from them, especially those in Mongolia. Despite this, Bawden praises Rehmann's efforts as being 'extensive' (Bawden 1973: 487), which is evident from the Literary Panorama of 1807 , where Rehmann reported his vaccination of a large number of Buryat children (Literary Panorama 1807). Rehmann had evidently been observing the lives of the Buryat closely, as a letter to his physician father dated 14 October 1806 regarding his vaccinations disclosed the ethnicity of the children; the letter was sent from the border town of Kyakhta, Buryatia, and also described in detail the lifestyles of the Buryat Mongols.

1 A Russian town in Buryatia, adjacent to Kyakhta on the border with Mongolia. 
Ultimately Russian interest in Mongolian healthcare took shape in the form of relief works to support the country. The arrival of Russian doctors specialised in their fields of work, such as in advanced areas of ophthalmology, of which Mongolians had very limited knowledge, provided a more efficient alternative to traditional treatments. ${ }^{2}$ In some ways Russian interest in Mongolia medicine was pragmatically self-interested: the proximity of the two countries meant that the severe outbreaks of infectious diseases such as the bubonic plague in Mongolia and Manchuria posed a threat to Russia. This fuelled the government's drive to deploy investigations in Mongolia to examine the conditions and provide support to reduce the gravity of epidemics. ${ }^{3}$ Multiple European medical journals highlight these activities, including by some British investigators who arrived in these areas. For example, the British Medical Journal archive contains some records of work regarding Mongolian tarbagan disease, also known as the bubonic plague, which was a severe threat to Mongolian health and trade. The significance of the poor health situation in Mongolia was thus emphasised, attributed to the observed inadequacies of the time. The increase of Russian interest in Mongolian healthcare was a reaction to this situation, even if this interest was geo-political in nature.

Further, it was through Russian finance that the first European-style hospital in Mongolia was established in 1909 (Batoev 1998: 16-17). As this institute treated Mongolian residents free of charge, European medicine in Mongolia was made more accessible than before. The innovative Western structure of the hospital involving two units, one dedicated to in-patients and one for outpatients, allowed for greater efficiency in medical care. The in-patient clinic especially allowed medical staff to provide more attentive services to severer cases for longer periods of time. In the long term, this set a new standard for medical care in Mongolia, so though initially the use of two units in Mongolian hospitals had been considered unorthodox, it became the model that most hospitals in the country are based on. The Russians had clearly intended the impact of this to be long term, as in addition to providing the crucial start-up finance for the hospital, a Russian diplomatic mission continued to provide 2000 rubles per year to support the maintenance and running of the institute. To complement this, the first pharmacy in Mongolia was set up in 1910 with financial support from a Russo-Chinese bank and the Kokovin \& Basov

2 Two ophthalmologists from St Petersburg hospital performed certain procedures for the restoration of eyesight. Reportedly, doctor O.P. Levistskaya and obstetrician Ye.A. Borodin worked alongside them (Maslova 2009: 139).

3 There had been a small influx of Russian doctors and investigators such as D.Yu. Zabolotny (in 1898) Yu. Talko-Gryntsevich (1899), Professor I.N. Lang and M.I. Podbelsky (1900), F.F. Syumivan (1901), M.Yu. Shreiber and V.I. Shendrikovsky (1905-06) to Mongolia (Krupskaya et al. 2016). 
Company, and in the same year, proposals for the creation of more state outpatient clinics in two towns were made by the Russian consulate in Urga for the towns Zaya gegen-ü khüree and Janjin wang-un khüree (Sizova 2015: 200). As these locations were places where numerous Russian citizens resided, Russian travel into Mongolia must have been an important impetus behind the Russian consulate's interest in Mongolian healthcare, especially as it greatly distrusted the traditional treatments. However, the proposals for the creation of these further clinics failed, possibly complicated by the uneasy domestic situation of Russia at the time.

The services of the doctor in charge of this hospital, Dr Sanjmyatav Budjapovich Tsybyktarov (1877-1921), attracted interest from figures from all levels of society, whether it was the Manchurian Amban (Qing administrator) to the ordinary Mongolian lay community, or people from as far as Tibet, all of whom sought medical help from him. Tsybyktarov, a Buryat Mongol of Russian nationality, was a key figure in the introduction of European medicine. In addition to performing medical services, he further taught anatomy in Mongolia to increase Mongolian understanding of European medical knowledge, which was especially important, as this article will discuss later. Despite this, Tsybyktarov's efforts and career were ended in 1921 after he was murdered by White Russians due to tensions regarding his support for the Bolsheviks. Though Tsybyktarov was a Russian Mongolian working for the Russian government, his services within the hospital and outside it helped both to expose European medicine in Mongolia and to disseminate medical knowledge, if only in a small way, directly into Mongolian understanding by means of the lessons that he taught.

As an arm of the Russian government, the Russian consulates were integral in the execution of medical policies in Mongolia, since it was they that implemented the policies. Facilitated by the nineteenth-century treaties between Russia and the Qing, the creation of a Russian consulate in Urga in 1861, followed by further consulates in Uliastai, Khovd and Sharasüme during the early twentieth century (Sizova 2016: $5^{-6}$ ), extended Russian influence into Mongolia. This allowed the Russian government to gain a new and deeper insight into health conditions in Mongolia. This greater understanding motivated and increased their medical intervention. Private doctors attached to each consulate began to extend their services to local Mongolian populations, having initially been reserved for Russian settlers, traders and diplomats in Mongolia. The encouragement of the first consul K.N. Boborykin (Consul 1861-63 in Urga) through his request for additional Russian practitioners to be sent into Mongolia increased this initiative, and the Russian consulates were established as centres of medical service (Edinarhova 2003: 250). According to Maslova (2009), V.P. Ovsyannikov reported that by 1906, it was clear that 
Mongolians had built a real dependence on the consulate's medical support. From a total of 13,449 patients who arrived at the Urga Russian Consulate for health services, 10,893 were Mongolian (Maslova 2009: 139). This also highlights the changing use of the consulate's medical programme, as now it was more used by the Mongolians than by the Russians.

Russian Consul Lyuba's desire in 1906 (during his services from 1904 to 1906 in Urga) to 'bring our people closer to the country and its population, and to attract popular sympathy to our side' (Darevskaya \& Svinin 1994: 121) was indeed coming to be the case on the side of the Mongols. The importance of trust emphasised in his words was reflected in Mongolian relations to Russia, as the benefits of European medicine increased Mongolian rapport. Sizova, who researched the Foreign Policy Archives of the Russian Empire, emphasises this Russian desire to increase trust and understanding between the nations, having found a statement made by the Russian consul in Urga from 1916 to 1919 that states this claim. Consul A.A. Orlov emphasised that '[b]y the works of our hospitals as well as by the power and knowledge of Russian doctors who enjoyed limitless respect and honour everywhere in Mongolia, the former distrust of Mongolians for European doctors quickly turned into a blind, unshakable faith' (Sizova 2015: 198). As an extension of the Russian government, the consulates demonstrated an evident intention to extend Russian political influence in Mongolia. However, the Russian consulates had a degree of their own agency, often suggesting and providing medical support to Mongolians through their own initiative. For example, the creation of Tsybyktarov's hospital was a result of their proactivity in trying to cope with the high demand for health services across Mongolia. Due to the severity of some health issues, the demand for medical care often exceeded the capabilities of the Russian military and consulate doctors. However, subordinate as they were to the Russian government, the impact of the Russian consulates would have been negligible if they had tried to act alone. The consulates were only able to implement services under the financing and resourcing that the government allowed them.

It is also misleading to assume that all Russian medical implementations in Mongolia were solely due to political and economic self-interest. K.N. Boborykin (Consul 1861-63) highlighted a certain sympathetic side to their medical support. Having asked for a doctor to come to the consulate to provide services to Mongolians, he wrote that ' $\mathrm{t}]$ his will be a truly good and Christian matter on our part regarding these poor people' (Maslova 2009: 139), thus indicating a sense of charity, though this might have been their justification of medical intervention for the purpose of medical colonialism as Christian charity. The same compassion is hinted at in Russian interest in the healthcare of the Mongolian military. The Russian Military Minister V.A. Sukhomlinov reported 
to Tsar Nicholas II in 1913 on the 'insurmountable difficulties' that the brigade was experiencing. Having been exposed to the severe venereal diseases and skin-related illnesses that were commonplace among the army while attempting to reorganise the Mongolian army, Sukhomlinov was the first to understand the urgency of the situation. An expedition was dispatched by the Russian Red Cross Society into Urga to tackle these issues, further providing Mongolians with experience of the benefits of European medicine. However, the impact of this was minimal in the long term, as the services were mainly administered by the Russians and the medical knowledge remained exclusively with the Russian doctor A.I. Makarevich, the medical assistant Gregory Burenkov and four nurses (Filin 2017:52-61). The urgency of the letter on the other hand, describing the rampant effects of disease, suggests a sense of sympathy, beyond the pragmatism of the request. The threat of Chinese occupation made the need for a strong military resistance force imperative. It was evident that the extremely poor health of the army had hindered the emergence of such a force; thus it was in both the Russian and the Mongolian interest to increase the quality of the Mongolian army.

In some ways, Russian traders profited most from the attraction of Mongolians to Russians that resulted from the administration of European medicine. The Russian promotion of animal immunisation in Mongolia benefitted Mongolian veterinary medicine and therefore also the Mongolian-Russian trade that was so heavily built on animal produce, though this was mainly in the interest of the Russian market. By bettering Mongolian trade through improving produce quality and commercial desirability, immunisation of animals optimised the produce that the Russians purchased, allowing them to take advantage of their exclusive right to duty-free trade in Mongolia that had been affirmed by the Treaty of St Petersburg in 1881 .

This privilege greatly accelerated Russian trade in Mongolia. Not long after this treaty, by the end of the nineteenth century, the Russian market alone constituted from 30 per cent to as much as 40 per cent of northern Mongolian trade and was still increasing. Russian-Mongolian trade grew from a turnover sum of 100,000 rubles in 1861 to around 1.7 million rubles in 1885 and 16.9 million rubles in 1900. Ultimately by 1910 the figure reached 25 million rubles (Ochir \& Enkhtuvshin 2004: 245-6). On the other hand, the increasing Russian influence in Mongolia was a cause of concern to the Qing authorities, as it threatened to tip the power balance in favour of the Russians. To undermine the Russian market, the Qing authorities supported Chinese trading activities with the purpose of pushing back the Russian influence in Mongolia (Natsagdorj 1963: 70), which probably limited Russian activity in some regions of the country. 
From the start of its use in 1919, which helped to increase Mongolian revenue (Filin 2017: 52-61), the extent of the benefits that Mongolians gained from Russian immunisation is still evident today, as Mongolians still purchase immunity vaccinations from Russia, in addition to their own from Mongolia. The better-quality produce bought from immunised animals was one of the measures that allowed the Russians to maximise their income from the almost onesided agreement that was signed in 1912. This agreement provided Russia with significant political and economic privileges, such as exemption from paying customs duties. This was a unique privilege granted to Russia, as the agreement prohibited it from being offered to any other country. As a result, Russian traders enjoyed exclusive business privileges in Mongolia (Sandag 1971: 45). This capitalisation on the Mongolian trading market came to be of greater interest to Russia as they began to experience increased competition from around another 20 trading agencies from Britain, France, Japan and America in the south of Mongolia, as well as a further 10 agencies based in Urga alone that dealt with the northern regions. However, thanks to the trust that had been built between Mongolia and Russia, the latter managed to maintain the upper hand in trading. The success of Russian trade in Mongolia owed much to the amiable relations between the two countries, thanks to proximity, trading agreements and the trust created through activities such as medical support.

The popularity of the marmot pelt trade from Mongolia, paired with the risks associated with the bubonic plague that sick marmots carried, further increased Russian medical interest in Mongolia. Through expeditions sent by the Russian government, the Russians discovered that this 'marmot poison', as the Mongolians called it, was the same disease known more conventionally worldwide as bubonic plague (Anonymous 1907). Posing a threat only to humans and marmots (Preble 1912), the plague threatened Mongolian-Russian trade as well as health. In addition to Mongolian territories that experienced outbreaks of plague, nearby areas such as Manchuria in China and the Trans-Baikal region in Russia also suffered from the disease on a yearly basis. Sizova reports that the action taken from the early 186 os was vaccination for several different diseases such as smallpox and plague, measures which had been initiated by consular doctors who passed on this knowledge to the Mongolians (Sizova 2015: 199). However, European medical practitioners had little understanding of the plague even by the turn of the twentieth century (Summers 2012: 7). Thus realistically, little could have been done to prevent the plague. In the light of this, reinforced by the fact that the plague vaccination was not actually discovered until 189o, Sizova's statement seems largely invalid regarding the plague vaccination. Even if it is likely that the smallpox vaccine was administered in the 186os, it would have been impossible for that for the plague to have taken place, unless Sizova was suggesting that this occurred much later, after 
the founding of the plague vaccination. The medical situation of the marmot pelt trade was directly linked with economics, especially for the Mongolians, as the trade had been prospering, multiplying 400-fold between 1906 and 1910. Export revenues totalled 13 million rubles in these four years, while back in 1865 it only came to a meagre 30,00o rubles (Summers 2012: 119-20).

Perhaps the most significant medical practice that the Russians, including Russian traders, endorsed was the use of the smallpox vaccination. The efforts of Russian traders promoted the broader use of vaccination in Mongolia which benefitted Mongolians more than inoculation. Though the mortality rate of inoculation was around 1-2 per cent, no vaccination patients died, which provided the Mongolians with a safer and more efficient alternative. Russian traders began to perform vaccinations on local populations to combat the staggering prevalence of smallpox outbreaks, which in turn elevated their own image among the Mongols. Similar to the efforts of the government, the exposure to the benefits of vaccination increased the Mongolian population's trust both in the use of vaccination and in the Russian traders, who benefitted from this favourable attitude. However, the lack of medical training of the Russian traders, suggests also a lack of genuine care for the well-being of the Mongolians. Medical assistance was evidently being used by the Russian traders to support their interests in bettering Mongolian and Russian trading relations and not to invest genuinely in the welfare of the Mongolians. Despite the significance of Russian promotion of vaccination, evidence of Mongolian awareness of the practice was available from as early as the beginning of the nineteenth century in the works of Mindol Hutugtu Jambalchoijidanzanperenlei (known as Mindol Hutugtu). ${ }^{4}$ Though commonly it has been suggested that the Russian medic Osipov was the first person to introduce smallpox vaccination into Mongolia (Filin 2017: 52-61), in reality it had been Mindol Hutugtu. However, the limited success of Mindol Hutugtu's promotion of the technique and lack of its later use suggests his failure to advance Mongolian preventative medicine. Thus, though the direct impact of the Russian traders was limited to the northern and western regions of Mongolia, the efforts of Russians in the introduction of smallpox vaccination into Mongolia were very successful in

4 To this day, Mindol Hutugtu was considered to be of Mongolian descent. However, Lobsang Yongdan stated he originally came from a Tibetan family in U lan mi ru, Amdo (Yongdan 2011 \& 2016), though according to Mongolian scholars, the fourth Mindol Nomun Khan [Tib. Smin grol no mun han or Eng. King of Dharma] was born in Toli [Eng. The Mirror] close to Ulaan Mörön, Kökönor [Eng. Red River, Blue Lake] modern-day Qinghai, China (Jigmed 20og: 233). Interestingly, Mindol hutagtu several times quoted 'our Tibetans' in his books. Superficially it gives the impression that he was a Tibetan. However Mongolians called Tibetans 'our Tibetans of the same religion' respectfully, due to the influences from them of Vajrayana Buddhism. 
familiarising Mongols with the benefits of vaccination in preventing smallpox as well as other diseases. Ultimately it was the Russians who had reintroduced the vaccination in such a manner that it was able to overtake the prevalent use of inoculation. It is possible that Mindol Hutugtu's impact regarding vaccination was prevented because of suspicions about the use of an animal-originated disease into the human body. However, due to the new Mongolian trust in Russia, paired with the lower mortality rate of the treatment, Mongolians began to appreciate the use of vaccination.

Mongolian rapport for Russians, that had been somewhat shaped by the efficiency of their medical services, drove Mongolians to welcome their arrival. As noted by Filin (2017), the Mongolians developed a genuine level of affinity with the Russians as can be seen in the trust they showed in allowing Russians to perform foreign practices on them. Filin's recounting of Potanin's (1892) description of the endearment used by Mongolians towards a Russian merchant as a 'dear friend' due to his support with the smallpox vaccination is an example of this rapport. In addition to this, relations between Mongolians and Russian medical staff often grew so strong that doctors such as P.A. Kornievsky, a member of the Fourteenth Russian Religious Mission (1858-64), came to be one of the most welcomed people in Mongolia (Filin 2017). Mongolian trust in the Russian advocacy of European medicine was evidently strong enough to cause the Mongolians actively and enthusiastically to seek their services, thus increasing European medical influence in their healthcare. This was noted in Dr V.P. Ovsyannikov's records in 1906 as previously mentioned, since an overwhelming majority of the patients at the Russian consulate in Urga were Mongolians (Maslova 2009: 139). It seems that to some extent Mongolians idolised the Russian traders, such as D.N. Yermolin from Biysk, glorifying them as 'kind Russian saviours' for giving vaccinations against disease (Filin 2017). This trust, fuelled between Mongolians and Russians, was extremely important in the integration of European medicine into Mongolia, as it convinced Mongolians to go beyond the teachings of their known traditional treatments.

In addition to Russians, other Europeans also promoted the familiarisation of European medicine to Mongolians. The Qing Empire was made a target for Christian missionaries and this created a small influx of them into Mongolia. Like the Russians, their recognition of the inadequate elements of Mongolian medicine was the basis for them to use medical intervention to extend their influence and facilitate the spread of Christianity. After 1897, Swedish missions to the Qing provided health examination-related services to Mongolians. 
Through the invitation of doctors and nurses into Mongolia, the Swedes ensured that Mongolians received proper care, along with the creation of institutions such as a clinic in Urga in 1920 that supported their medical services. This resolved the issue of the inadequacies of the facilities they experienced in Mongolia. However, similarly to how the Qing had repressed Russian activity when they wielded greater authority over Mongolia, the Russians could now repress Swedish activity after the beginning of the twentieth century; they coerced the mission to relocate to Kalgan ${ }^{5}$ in 1924, which disrupted the Swedish activities and reduced their contact with people from the north of Mongolia. Evidently the Russians sought to preserve their own influence in Mongolia, and did not genuinely care for the welfare of the Mongolian population, nor the implementation of European medicine to benefit society. Their removal of Swedish intervention demonstrates that their interests lay with maintaining control over Mongolia.

Yet these vital moments of contact had been significant in increasing Mongolian medical understanding of infectious diseases, and this helped the government's healthcare projects from 1921. Having worked in Mongolia since 1914, Swedish physician Joel Eriksson (1890-1987) was able to observe closely and identify the many skin and venereal diseases that affected members of all different statuses in society. As meticulously noted by American traveller Roy Chapman Andrews (1884-1960) (Andrews 1932: 351), ${ }^{6}$ Eriksson's suggestion that the spread of venereal diseases could be attributed to the illicit sexual activities of Mongolian monks was vital in the Mongolian government's attempts to reduce the impact of these diseases after 1921. However, some pieces of information were incorrect, such as the suggestion that the spread of venereal diseases was due to shared pipe smoking; but this is understandable since at the time very little was known about these diseases anyway. So, though there was little immediate impact, Eriksson's works served to form a foundation for the Mongolian government's future internal state policies regarding public health.

However, not all medical services were driven by the interests of European countries. Scottish missionary James Gilmour (1843-91) showed genuine concerns for Mongolian healthcare, extending European practices into the more inaccessible regions of Mongolia. He often visited Mongolia, working with around 6ooo patients in the space of eight months on one of his stays (Royer 1914:117); and he also extended his visits into areas of closer Qing rule, increasing exposure to European medicine in the south of Mongolia. There is also

5 A town in the south of Mongolia.

6 Andrews had led the Central Asian expeditions of the American Museum of Natural History from 1921 to 1930. 
some evidence that other British missionaries acted as medics in Mongolia at the end of the nineteenth century, such as Frederick Charles Roberts (1862-94) and Thomas Cochrane (1866-1953). Cochrane travelled on a medical mission to Mongolia after graduating in medicine from Glasgow University in 1896 (Anonymous. 1954: 47). Similarly, Gilmour and Roberts were assigned to provide medical services in Mongolia on their mission, but unlike Roberts (who decided to stay and focus on China upon his arrival there in 1887), Gilmour remained to accomplish this (Bryson 1895: 8). Gilmour genuinely wanted to provide Mongolians with the medical support that they lacked. His close relationship with the Mongolians allowed him to observe and produce information that was vital for Mongolian medical knowledge. From his observations highlighting the severity of the health-related situation in Mongolia, the significance of the poor health conditions in Mongolia was established, and this attracted the attention of the Europeans.

Gilmour was able to identify some of the most common diseases among Mongolians such as ocular diseases, rheumatism, skin diseases, 'spring disease' and a disease called narry [oesophageal cancer]. His identification of the cause of narry (in modern Mongolian, nariintah övchin) as alcoholism was valuable to the government's understanding of public health. The identification tallied with the increasing level of alcohol consumption in Mongolia; this made his case for the severity of the disease (which resulted in the sufferer's death through starvation, as its symptoms prevent the patient from being able to eat) much stronger, as he recorded, noting the prevalence among the population (Gilmour 1883: 178). It was evident that he made intimate observations of the Mongolians, empathising with them and recognising the implications of their livelihoods. For example, he was able to identify that the 'spring disease' (an illness that affected both people and cattle) was indicative of the physical hardships that Mongolians and their livestock endured during the severely cold winters, leaving them exhausted and vulnerable to illnesses in the springtime. His evident care for the Mongolians earned him the affectionate nickname 'our Gilmour' from the Mongolians.

\section{$4 \quad$ Efforts from within Mongolia}

Mongolians also contributed to the import of European medical knowledge into Mongolia through their own efforts. Exposure to beneficial new knowledge made some Mongols challenge their current medical understanding, encouraging them to use the new connections with Russia to increase their understanding of anatomy. As mentioned before, Tsybyktarov taught lessons 
to monastic lama doctors to integrate European anatomical understanding directly into Mongolian knowledge. The prohibition of surgery, having been implemented after a surgical failure on the mother of the Tibetan King in the eighth century, resulted in the shift of Tibetan doctors' focus away from surgery to natural medicine (Ward 1991: 198-205). Because healthcare was provided by monks in Mongolia, Mongolian doctors followed suit, which massively restricted their understandings of surgery. The last Tibetan medical practitioner to incorporate European practices into Buddhist healthcare had probably been Yuthog Yontan Gonpo in the eighth century, who added Galen's' medical theory and practices to Tibetan medical knowledge. ${ }^{7}$ However, as the general Mongolian public did not feel personal loyalties to Tibetan traditions outside religion, when surgical methods started being used, they felt no need to restrict their use. With their history of warfare, which involved the use of surgery for traumatic injuries, as well as the examples taken from the European influences, they easily accepted surgical treatments. Prior to the interventions from Europe, there had been the potential for the development of Mongolian anatomical knowledge. A Mongolian version of the Manchu Anatomy, which accurately presented key anatomical studies from both Europe and Asia, provided a model for this. However, as the only copy available in Mongolian was made inaccessible by being stored away in Beijing, its impact in Mongolian medical knowledge until after 1921 was minimal.

Yet, though it encouraged scholars to explore medicine further, increased familiarisation with European anatomical knowledge in Mongolia fuelled internal divisions among Buddhist lama doctors. Due to the overall influence of Tibetan Buddhism, and in turn Buddhism in medicine, though they felt no direct link to specifically Tibetan traditions, the more conservative lamas felt wary of these new practices. They were able to prohibit other monastic doctors from attending Tsybyktarov's anatomy class, thanks to the fact that they typically were of higher status and authority (Maiskii 1959: 310). Thus, though the more open-minded lamas were integral in the introduction of anatomical knowledge into Mongolian medicine, conservativeness was an inhibiting force preventing its full integration. Yet the fact that these events occurred is significant in itself; as the study of European anatomical knowledge in the Buddhist Züün Khuree College that Byambyn Rinchen (1905-77) referred to in the introduction of his 1971 reprint and Mongolian translation of the Manchu Anatomy (Unknown [Parranin] 1971: 3-5), the study of European medicine

7 A distinguished physician, Yuthog Yontan Gonpo the Elder fused medical knowledge from multiple different medical traditions from both Western and Eastern medicine to create the foundation for Tibetan medicine. 
in general in Mongolia was unusual. Due to the importance of Buddhism in both Mongolian society and Mongolian healthcare, often European ideas and teachings that did not align with Buddhist beliefs were immediately rejected, upholding Buddhist dogmatism as the most dominant force in Mongolian medicine for centuries.

Nevertheless, the Eighth Bogd Gegen, the spiritual and secular leader of Mongolia, attempted to shift Buddhist dogmatism and encourage the practice of European surgery. Bogd Gegen had a role in the import of a Russian textbook on anatomy into Mongolia as well as in the creation of a surgical unit, and he was able to become personally involved in its practices, performing surgeries on people himself (Maiskii 2005: 367 ). Though the advocacy of such an important political and religious leader for European medicine probably promoted its use to some extent, on the whole many were deterred from its practice after sad results from several surgeries for which he was responsible. Evidently this caused concern among the medical community and resulted in the sudden destruction of his surgery, suggesting the extent of the distress that his actions had caused. Though it was reported to him that a fire, caused by lightning, had burnt his practice down, in reality it was more likely to have been caused by concerned monks who were desperate to stop his failing surgical attempts. Either way, whether it was an act of defiance and protest from the monks or an ominous coincidence of lightning hitting the unit, there was disapproval of the Bogd Gegen's use of European medical knowledge and practices. The consequence of this was increased condemnation of the use and trust of European practices by the conservative monks to all in Mongolia.

Before Bogd Gegen, it was Mindol Hutugtu's works that had provided most knowledge about European medicine and surgery. As early as 1830, Mindol Hutugtu had attempted to spread knowledge of practices like vaccination and use of medical plasters in The Treasury of All Precious Instruction. The European method of opodeldoc liniment (soap liniment, a medical plaster preparation), mentioned by Uspensky (2009: 222-7) and the smallpox vaccination, discussed by Lobsang Yongdan (2016: 577-93) were key European techniques brought to Mindol Hutugtu through Russian missionaries during the Qing rule in the nineteenth century. Mindol Hutugtu was introduced to European medical practices by physicians such as Osip Pavlovich Wojciechowskiy (1793-1850) and an army officer Osip Mikhailovich Kovalevskiy (1801-78) (Uspensky 2009). All this showed the potential for the growth in Mongolian medical understanding of aspects that traditional medicine could not cover, but it was just unfortunate that Mongolian society at the time was unwilling to understand the new ideas. By not dogmatically limiting himself to traditional Buddhist healing practices, Mindol Hutugtu showed an understanding of medicine beyond 
his time. In addition to knowledge of these widespread European practices, Mindol Hutugtu's fascination with European surgical treatments is evident in his description of several important surgical techniques such as uvulectomy ${ }^{8}$ and the procedure of ligation in the thyroid artery for goitre. His instruction on how to reduce blood circulation for the enlarged thyroid gland was an especially progressive therapeutic method of that time. Mindol Hutugtu noted that in order to treat the enlarged goitre, the initial treatment was to apply a medicine of plant and animal origins and a soup made of the thyroids of animals such as wolves and birds, for three days. The goitre artery located 'behind the ear' must be cut off and tied up. ${ }^{9}$ Here, although it seems that 'the goitre artery' behind the ear was to be cut, it is possible that he is referring to the superior thyroid artery to the gland. Though we can find no direct links in the writings of Mindol Hutugtu, it was interesting that the first attempt at ligation surgery on this artery had been attempted unsuccessfully in 1813 in a London hospital by Sir William Blizard—around 17 years before the publication of Mindol Hutugtu's medical works - while a successful one was performed a year later in 1814 by Walther of Landshut (Rogers 1929). It is possible, because of the closeness of the dates, that Mindol Hutugtu was referring to these attempts, but, be that as it may, his works were never really widely accepted by medical communities in Mongolia until the twentieth century.

The avoidance of medical practices unorthodox to traditional Mongolian treatments was finally overcome due to the series of historic changes in Mongolia in the early twentieth century, which combined to promote the adoption of European medicine. During 1914-15, Outer Mongolia was allowed autonomy while Inner Mongolia remained a part of China under the ChinaMongolia-Russian Tripartite Conference. In 1919, the Urga government was eliminated by Chinese forces; in 1921, it was re-established by White Russians, and soon afterwards the Mongolian People's Revolution took place. Backed by the Red Russians, the People's Republic of Mongolia was established. The Mongolian authorities invited Russian doctors into the country and the use of the traditional Buddhist medicine was prohibited in 1924. This initiated the subordinate period of traditional Mongolian medicine, which fell under the shadow of European practices until the 199os.

8 Jambalchoijidanzanperenlei 2007: 519 .

9 Shin tu yung ring nang nas har ba la spyang gii lba sha bsdus pa'i thang gis phul zhag gsum bsten rjes rnam rgyal lba rtsa de gcad nas mig ste zum du jug go rna rgyab lba rtsa bcad rjes khab so legs la khyi spu drangs pas mig de zum du lba ba bug pa dang 'dra bar skud pa rgyu mi gzhug (Jambalchoijidanzanperenlei 2007: 358). 
The benefits of European medicine and its scientific methodology were its efficiency in surgery and the prevention of infectious diseases. This filled in in the gaps in traditional Mongolian medical knowledge. The most direct benefit that Europeans experienced was an increased level of trust from the Mongols, which increased their popularity and thus promoted their own cultural, political or economic interests. The Russian government was the most successful in gaining Mongolian trust, and it is argued here that the systematic exposure of European medicine to the population was an important means whereby Russia was able to extend its influence in Inner Asia. Through their exploitation of medicine, the Russians encouraged Mongolia's political dependency, gradually eliminating the threat of loyalty to the Qing and maintaining their position by pressurising other foreign powers to leave the region. Due to their geographical proximity and the forcing through of several treaties that cemented their power in Mongolia, the Russians experienced certain privileges that benefitted their colonial endeavours and gained an advantage over other Western European groups, who, despite having similar desires to extend their influence, were less successful in doing so.

For the most part, the Russian government's degree of genuine care for Mongolian healthcare was limited by their political and economic agendas. This is shown by the way they manipulated the use of European medicine among Mongolians. Notably, they kept the practice of European medicine almost entirely to their own doctors, so though Mongolians benefitted from the efficiency of European medicine, they were never helped to be independent, always having to rely on external powers to provide them with this service. Thus, the main effect that European medicine from Russian had on Mongolia at the beginning of the twentieth century was its deepening of reliance on the Russian government, increasing Russian political reach as well as economic benefits for Russian traders. This in turn encouraged the further increase of Russian medical support in Mongolia to perpetuate political dependency. Meanwhile, though the Qing had initially been the main reason for the prevention of the entry of European medicine in the early nineteenth century, their waning position in Asia made the country attractive to European missionaries. Observing the poor health conditions on their journeys, the medical services the missionaries provided elevated their image and thus promoted their ideas.

However, this did not have a significant effect, as the main focus of the missionaries was to reach China; Mongolia was only a stop on the way, and while there, very few paid real attention to the situation. More importantly, the impact of the Qing in preventing the use of European medicine in Mongolia was 
not intentional and was just a repercussion of their primary political goal: to maintain their hegemony in Mongolia. It was just an indirect consequence of their attempt to maintain greater power in the region than Russia. In this situation, some Mongolian figures were not passive recipients of European medicine. Given the fact that conservative monks typically resisted both its practice and teaching, when it did occur the synthesis of European knowledge and practice in Mongolian and Tibetan medicine was an astonishing accomplishment. This had probably not happened since Yuthog Yontan Gonpo the Elder in the eighth century. Overall, the main factors that prevented the dissemination of European medicine in Mongolia were the political aims of the Qing (and later the Russians), the vastness of Mongolian territories, as well as generational conflicts and suspicions to new ideas in Mongolia.

The period after the Mongolian People's Revolution in 1921 has been celebrated as the pivotal point for the introduction of European medicine in Mongolia. Though in many ways this is accurate, as it was the prohibition of traditional Mongolian practices after 1924 in an attempt to implement Russification policies that led to this, it is important to examine the elements of exposure and low levels of integration of European medicine into Mongolia before this period. The foundation of the current state of the combined practice of European and traditional Mongolian Buddhist medicine was seeded mainly during the period from the 186os until 1921, though elements are suggested before this timeframe too. After all, it was this prior familiarisation of the benefits of European medicine that increased Mongolian trust, then later dependence on Russia, which encouraged the Mongols to depend more on European medicine.

\section{References}

Andrews, R.C. 1932. The New Conquest of Central Asia: A narrative of the explorations of the Central Asian expeditions in Mongolia and China, 1921-1930. New York (NY): American Museum of Natural History.

Anonymous. 1907. Plague and the 'tarbagan' disease in Mongolia. The Lancet 170: 1630. Anonymous. 1954. Obituary. British Medical Journal 1: 47.

Batoev, D.B. 1998. Pervyi doktor kyakhtinskikh buryat [The first doctor of Kyakhtas' Buryat]. Zakamensk: Buryat. Izdatel'stvo.

Bawden, C.R. 1973. J. Rehmann and A. Thesleff: Mongoleireise zur spaeten Goethezeit: Berichte und Bilder des J. Rehmann und A. Thesleff von der russischen Gesandtschaftsreise 1805-06 [book review]. Bulletin of the School of Oriental and African Studies 36(2): 486-8. 
Bryson, M.I. 1895. Fred C. Roberts of Tientsin: or, For Christ and China. London: Allenson. Darevskaya, E.M. \& B.B. Svinin. 1994. Sibir' i Mongolija: očerkirussko-mongol'skih svjazej v konce XIX-načale XX vekov [Siberia and Mongolia: Essays on Russian-Mongolian relations at the end of the 19th and beginning of the 2oth centuries]. Irkutsk: Izdatel'stvo Irkutskogo universiteta.

Edinarhova, H.E. 2003. Russkie v Mongolii: osnovnye ètapy i formy èkonomičeskoj dejatel'nosti (1861-1921) [Russians in Mongolia: the main stages and forms of economic activity (1861-1921)]. Irkutsk: Irkutskogo gosudarstvennogo universiteta.

Filin, S.A. 2017. Formirovanie evropejskih sistem zdravoohranenija i veterinarii v Mongolii v XIX-XX vekah [The formation of the European healthcare systems and veterinary medicine in Mongolia in the 19th-2oth centuries]. Istorija mediciny 4(1): $5^{2-61 .}$

Gilmour, J. 1883. Among the Mongols. New York (NY): American Tract Society.

Jambalchoijidanzanperenlei ['jam dpal chos kyi bstan 'dzin 'phrin las]. [around 1830] 2007. Man ngag rin chen 'byung gnas [The Treasury of All Precious Instruction]. pe cin: mi rigs dpe skrun khang.

Janes, C. \& C. Hilliard. 2008. Inventing tradition: Tibetan medicine in the postsocialist contexts of China and Mongolia, in L. Pordie (ed.), Tibetan Medicine in the Contemporary World: Global politics of medical knowledge and practice: $35^{-61 .}$ Abingdon: Routledge.

Jigmed, B. 2009. Mongol Anagaakh Ukhaanii Tuukh Bolon Ertnii Survalj Bichgiin Shinjilgee [History of Mongolian Traditional Medicine and Analysis of Ancient Sources]. Ulaanbaatar: Soyombo Printing.

Krupskaya, T.S. et al. 2016. Rol' Irkutskogo gosudarstvennogo medicinskogo universiteta v podgotovke medicinskih kadrov dlja Mongolii [The role of Irkutsk Medical University in the training of medical personnel for Mongolia], in I.V. Malova et al. (eds), Rol' medicinskih vuzov v podgotovke medicinskih kadrov: Istoričeskie aspekty [The role of medical schools in the preparation of medical personnel: historical aspects]: 32-7. Irkutsk: INCHT.

Literary Panorama. 1807. (Observanda externa). Frontiers of China. Vaccination, \&c. Portable medicine chests. The Literary Panorama 3: col. 199. London: Cox, Son \& Baylis.

Loewenthal, R. 1970-71. Reviewed work: Walther Heissig (ed.), Mongolenreise zur späten Goethezeit: Berichte und Bilder des J. Rehmann und A. Thesleff von der russischen Gesandtschaftsreise 1805/o6. Monumenta Serica 29: 781-3.

Maiskii, I.M. 1959. Mongoliya Nakanune Revolyutsii [Mongolia on the eve of the Revolution]. Moscow: Izdatelsvo vostochnoi literatury.

Maiskii, I.M. [1921] 2005. Orchin üeïn Mongol: Avtonomit Mongol 20-r Zuunii Garaan Deer [Contemporary Mongolia: Mongolian autonomy: at the start of the 2oth century] (trans. Otqon Tsagaan). Ulaanbaatar: Admon. 
Maslova, L.G. 20o9. Vklad russkih vračej v razvitie mediciny i otrasli zdravoohranenija v Mongolii [Contribution of Russian doctors to the development of medicine and healthcare in Mongolia], in Solongo, D. (ed.), Russkie v Mongolii [Russian in Mongolia]: 139. Ulaanbaatar: Mōnkhiin Üseg press.

Natsagdorj, Sh. 1963. Khalkhïn Tü̈̈kh [History of Qalqa]. Ulaanbaatar: Ulsiin Khevleliin Gazar.

Ochir, A. \& B. Enkhtuvshin. 2004. Mongol Ulsiin Tuukh [History of Mongolia] IV. Ulaanbaatar: Admon.

Preble, P. 1912. The Tarbagan (Arctomys bobac) and plague. Public Health Reports (18961970) 27:31-9.

Rogers, L. 1929. The thyroid arteries considered in relation to their surgical importance. Journal of Anatomy 64(1): 50-61.

Royer, G. 1914. Christian Heroism in Heathen Lands. Elgin (IL): Brethren Publishing House.

Sandag, Sh. 1971. Mongoliin uls tōriin gadaad khariltsaa 1850-1919 [Foreign political relations of Mongolia, 1850-1919], vol. 1. Ulaanbaatar: Shinjlekh Ukhaanii Academiin Khevlekh Üildver.

Sizova, A. 2015. Konsul'skaja Služba Rossii v Mongolij (1861-1917) [Consular Service of Russia in Mongolia (1861-1917)]. Moscow: Nauka, Vostočnaja literatura.

Sizova, A. 2016. The Political Role of the Russian Consulates in Mongolia in the Mongolian National Liberation Movement in the Early 2oth Century. Moscow: National Research University Higher School of Economics.

Summers, W. 2012. The Great Manchurian Plague of 1910-1911: The geopolitics of an epidemic disease. New Haven/London: Yale University Press.

Unknown [Parranin]. 1971. Deger-e-če toġtaġaġsan dursu-yin tusburi-ii buridgegsen bicig [Manchu Anatomy] (trans. Unknown). Ulaanbaatar: Shinjlekh Ukhaanii Academiin Khevlekh Üildver.

Uspensky, V. 2009. Josef Kowalewski and Minjul Hutugtu (1789-1839). Rocznik Orientalistyczny 62(1): 222-7.

Ward, M. 1991. Medicine in Tibet. Journal of Wilderness Medicine 2: 198-205.

Yongdan, Lobsang. 2011. Tibet charts the world: The Btsan po No mon han's Detailed description of the world, an early major scientific work in Tibet. In Mapping the modern in Tibet. Edited by Gray Tuttle. Andiast, Switzerland: International Institute for Tibetan and Buddhist Studies GmbH. 73-134.

Yongdan, Lobsang. 2016. The Introduction of Edward Jenner's smallpox vaccination to Tibet in the early 19th century. Archiv orientální 84(3): 577-93. 